\title{
An Assessment of Women Participation in Community-Based Natural Resource Conservation in Southeast Zimbabwe
}

\author{
Clayton Mashapa ${ }^{*}\left(\mathbb{0}\right.$, Patience Zisadza-Gandiwa2\#, Elias Libombo ${ }^{3 \dagger}$, \\ Patience Mhuriro-Mashapa ${ }^{4}$, Never Muboko' ${ }^{1}$ Edson Gandiwa ${ }^{1}$
}

\author{
${ }^{1}$ School of Wildlife, Ecology and Conservation, Chinhoyi University of Technology, Chinhoyi, Zimbabwe \\ ${ }^{2}$ International Coordination Office for Greater Mapungubwe Transfrontier Conservation Area, Causeway, Zimbabwe \\ ${ }^{3}$ Scientific Services, Gonarezhou National Park, Chiredzi, Zimbabwe \\ ${ }^{4}$ Department of Agricultural Economics, University of Zimbabwe, Harare, Zimbabwe \\ Email: *clayiemashapa@yahoo.co.uk
}

How to cite this paper: Mashapa, C. Zisadza-Gandiwa, P., Libombo, E., Mhuriro-Mashapa, P., Muboko, N. and Gandiwa, E. (2020) An Assessment of Women Participation in Community-Based Natural Resource Conservation in Southeast Zimbabwe. Open Journal of Ecology, 10, 189-199. https://doi.org/10.4236/oje.2020.104013

Received: February 19, 2020

Accepted: April 19, 2020

Published: April 22, 2020

Copyright $\odot 2020$ by author(s) and Scientific Research Publishing Inc. This work is licensed under the Creative Commons Attribution International License (CC BY 4.0).

http://creativecommons.org/licenses/by/4.0/

\begin{abstract}
The study assessed women's participation in the Communal Area Management Programme for Indigenous Resources (CAMPFIRE) activities in southeast Zimbabwe. The study collected data using an interview questionnaire administered to five CAMPFIRE committees in October 2014. There were relatively no differences in the selected attributes on CAMPFIRE committee composition across the five study communities i.e., 1) the number of people and their level of education, and 2) gender and age composition. There were more men $(5 \pm 0.11)$ than women $(2 \pm 0.02)$ in CAMPFIRE program committees across the five study communities. Men dominate leadership and decision making over CAMPFIRE in south-eastern Zimbabwe. Yet, it is the women who use most of the natural resources at household level, such as game meat, wild fruits and wild vegetables as relish, fuel wood as source of energy for cooking, and baskets woven from woodland products. It was concluded that despite all the benefits that a gender sensitive approach could bring to CAMPFIRE, women participation in CAMPFIRE programs in southeast Zimbabwe was still low as evidenced by their numbers in committees that make decisions for the program. There was need for deliberate action to ensure increased women participation in CAMPFIRE programs, especially at the decision-making level. A certain number of committee positions in CAMPFIRE should be reserved for women.
\end{abstract}

"Present address: International Conservation Affairs, Zimbabwe Parks and Wildlife Management Authority, Harare, Zimbabwe.

${ }^{\dagger}$ Present address: Community Liaison Division, Gonarezhou National Park, Chiredzi, Zimbabwe. 


\section{Keywords}

CAMPFIRE, Empowerment, Gender, Natural Resource, Women, Southern Africa

\section{Introduction}

The rural poor in developing countries remain directly dependent mostly on raw natural resources for their food and livelihood security [1]. However, dependence on natural resources is contextualised within socio-cultural parameters and shaped by differences embedded in societies, such as power, age and gender differences [2] [3] [4]. Gender issues are increasingly attracting attention in the community-based natural resource management (CBNRM), policy making or project implementation where stakeholders question the relevance of gender in natural resource conservation [5] [6] [7], especially about attitudes. For instance, CBNRM fails to recognize the roles and differences between men and women about demands, access and control of natural resources and knowledge capacities [3] [8]. Women are important natural resource users and their participation in CBNRM activities can create a platform for their empowerment and enhance their role in decision-making, including benefit sharing [2]. Allowing women to actively participate in initiatives that are related to their traditional roles and household chores is essential in enhancing women's participation and improved benefits and is desired by women in most of the conservancies and CBNRM programmes studied elsewhere in southern Zimbabwe [1] [2] [4] [6] [7] [8].

The need to address gender-sensitive concerns is pronounced in CBNRM initiatives like community areas management programme for indigenous resources programme (CAMPFIRE) in Zimbabwe. For instance, one of the principles of the CAMPFIRE program is stated as: "To support equal opportunities for all members of the community regardless of race, gender or political affiliations and work to train and empower women as effective participants in the economic development of the community" [4]. CAMPFIRE on communal areas adjacent to national parks was one of the key initiatives adopted to generate benefits, promote conservation, and empower local communities in Zimbabwe [9] [10]. The CAMPFIRE approach was instrumental in instilling pride and conservation on communally owned lands in Zimbabwe [11], while at the same time creating opportunities for local employment and community infrastructural development [8] [12].

The idea behind the CAMPFIRE program was to ensure that natural resources use meets today's needs, while conserving them for future generations [13]. This requires action to develop capacities, from global to grassroots level, for their sustainable management and regulation [14]. Understanding the role of gender in human relationships with natural resources is one of the precursors to more sustainable management of the environment [15]. Women and men use, access natural resource products, land and ecosystem resources in different ways. 
When such differences are properly understood, actions can be targeted to address the gender sensitive varied needs of resource users [16]. The present study focused on the role of women's participation in CBNRM, i.e., CAMPFIRE in southeast Zimbabwe.

To date, there has been little research on community-based natural resource utilisation and conservation that takes into consideration the assessment of gender mainstreaming in CAMPFIRE programs [8] [17]. In general, our understanding of gender differences in attitudes toward conservation, especially in sub-Saharan African communities is poor [18] [19] and this can impede natural resource management and conservation outcomes. Therefore, the objectives of this study were twofold, 1) to assess the role of women in decision-making processes in natural resources conservation in CAMPFIRE communities adjacent to Gonarezhou National Park, south-eastern Zimbabwe, and 2) to determine local people's views on the effectiveness and potential of CAMPFIRE programs with a gender perspective approach.

\section{Materials and Methods}

\subsection{Study Area}

Gonarezhou National Park is located between $21^{\circ} 00^{\prime} \mathrm{S}-22^{\circ} 15^{\prime} \mathrm{S}$ and $30^{\circ} 15^{\prime} \mathrm{E}-$ $32^{\circ} 30^{\prime} \mathrm{E}$, is the second largest protected area in Zimbabwe, with a spatial extent of $5053 \mathrm{~km}^{2}$ (Figure 1). The park and its surrounding communal area under

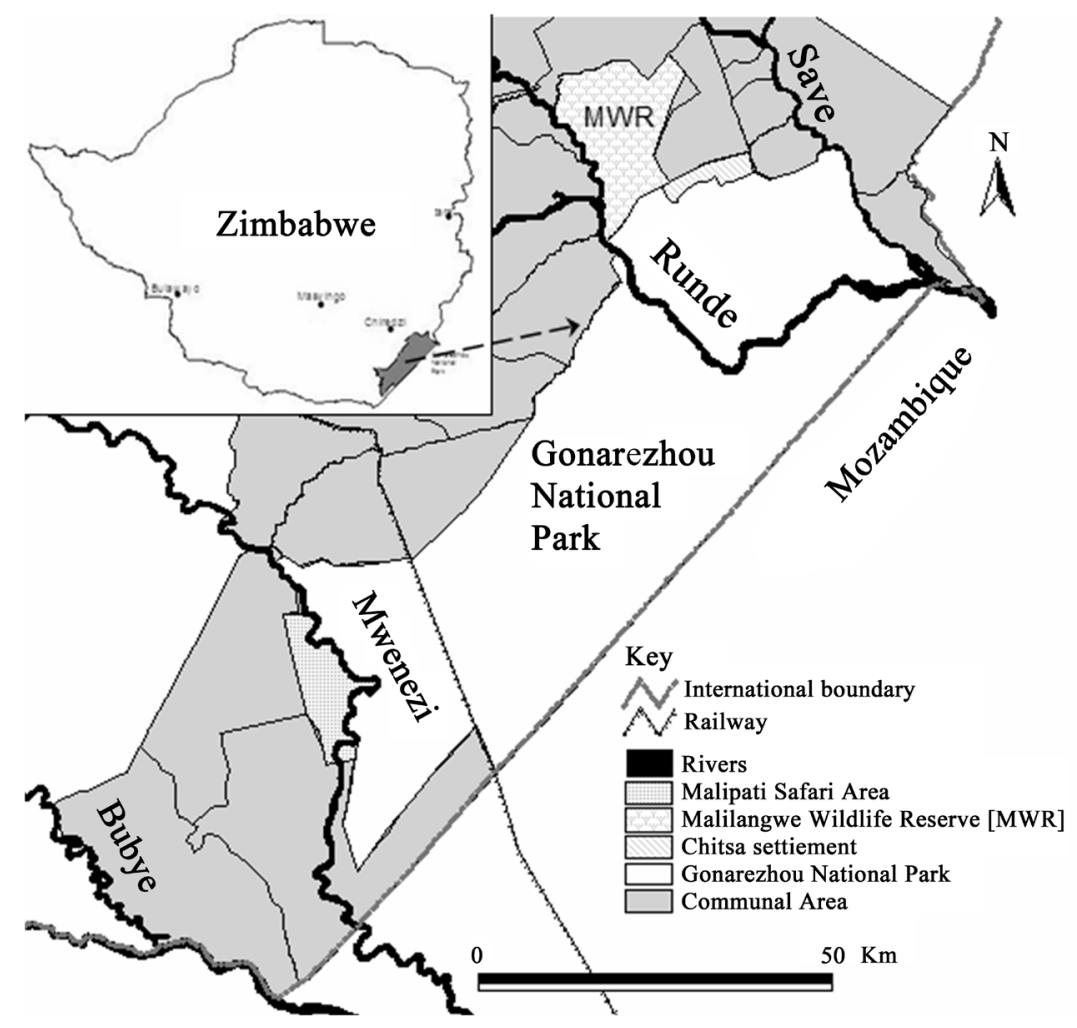

Figure 1. Location of Gonarezhou National Park and the surrounding communal areas in south-eastern Zimbabwe. 
CAMPFIRE are endowed with diverse animal, plant, bird and fish species [20] [21]. This study focused on five randomly selected communal areas (i.e., Muhlanguleu, Chini, Chibhavahlengwe/Masukwe, Chingele and Chibhavahlengwe/ Phahlela) surrounding Gonarezhou National Park, Chiredzi District, south-eastern Zimbabwe. These communities practise community-based natural resource management under the CAMPFIRE program. The implementation of the CAMPFIRE program in the study area started in the early 1990s [22].

\subsection{Data Collection and Analyses}

The study used an interview-administered questionnaire to collect data in October 2014 [23]. Pre-testing was conducted in two CAMPFIRE committees, outside of the study communities to ensure that all questions were clear, and a final version of the questionnaire was prepared for data collection. Interview dates were communicated to the five purposively selected CAMPFIRE Ward committees one or two days in advance. Before conducting the interviews, the general purpose of the study was explained.

The questionnaire included both open-ended and fixed response questions on the role of women in the CAMPFIRE programs in south-eastern Zimbabwe. We specifically addressed the following topics: 1) number of people and level of education in the CAMPFIRE committee, 2) gender and age composition in the CAMPFIRE program committees, 3) reasons for the involvement or non-involvement of women, 4) opportunities for gender sensitive CBNRM as enshrined by the CAMPFIRE constitutions, and 5) suggestions for further improving the CAMPFIRE programs through a gender sensitive perspective by engaging women in CBNRM. Interviews were held with secretaries of five CAMPFIRE committees since these have good knowledge of CAMPFIRE programs across communities. Interviews were conducted in English and lasted about 30 minutes.

Descriptive statistics were used to summarize and analyze the interview response data. The median as a measure for central tendency and the range to represent the variability in response data were computed for some of the interview response data. Data were grouped and summarised per response category, with data on the reasons for the involvement or non-involvement by the women, opportunities for involving women in CAMPFIRE programs and suggestions for further improving the involvement of women in natural resources management. These were qualitatively analysed based on emerging themes.

\section{Results and Discussion}

There were more men $(5 \pm 0.11)$ than women $(2 \pm 0.02)$ in CAMPFIRE program committees across the five study communities (Table 1). Women involved in CAMPFIRE programs were mostly of the age 25 - 40 years and the majority had attained secondary education level. Having few women in CAMPFIRE committees was attributed to the following: 1) a higher proportion of the women were 
less educated, 2) local traditional custom of married women limit them from active participation, and 3) women were not often voted for and/or elected by local people. Apart from being few in the leadership of the CAMPFIRE programs, the few elected women were reported as the trusted members of the CAMPFIRE committee in the management of financial resources. However, most women were reported left out of the CAMPFIRE committee because they are pre-occupied with family needs, such as walking long distances in search of fuel wood, gathering wild foods and other natural resource products [24] [25].

All study CAMPFIRE committee respondents reported that the involvement of women was important as women are more trusted to manage financial resources and that more women should preferable be involved in the CAMPFIRE committees as opposed to some men who are relatively more corrupt. The existing CAMPFIRE constitutions were reported not to be addressing the issue of women participation in the CAMPFIRE programs (Table 2). The reported limited participation of women could be the cultural remnants of the original and indigenous Hlwengwe (Shangaan) traditional custom and norms of the present people around Gonarezhou National Park [24] [26] [27]. More so, at national level in Zimbabwe, just like most African countries, men predominate as government representatives and civil servants, from the cabinet to the village level

Table 1. CAMPFIRE Committees composition across the study area.

\begin{tabular}{|c|c|c|c|c|c|c|}
\hline \multirow[b]{2}{*}{ Attribute } & \multicolumn{5}{|c|}{ Wards settlement as study sites } & \multirow[b]{2}{*}{ Mean $\pm S E$} \\
\hline & Muhlanguleu & Chini & $\begin{array}{l}\text { Chibhavahlengwe/ } \\
\text { Masukwe }\end{array}$ & Chingele & $\begin{array}{l}\text { Chibhavahlengwe/ } \\
\text { Phahlela }\end{array}$ & \\
\hline Total number of members in the CAMPFIRE committee & 7 & 7 & 7 & 7 & 7 & $7 \pm 0.01$ \\
\hline Number of men in the CAMPFIRE committee & 5 & 5 & 5 & 4 & 6 & $5 \pm 0.11$ \\
\hline Number of women in the CAMPFIRE committee & 2 & 2 & 2 & 3 & 1 & $2 \pm 0.02$ \\
\hline Age group of women in the CAMPFIRE committee & $25-40$ & $25-40$ & $25-40$ & $25-40$ & $41-60$ & $25-40$ \\
\hline $\begin{array}{l}\text { Number of women in the CAMPFIRE committee with at } \\
\text { least a secondary education level }\end{array}$ & 2 & 2 & 2 & 2 & 0 & 2 \\
\hline
\end{tabular}

Table 2. CAMPFIRE Committee members' views on the effectiveness and potential of CAMPFIRE programs with a gender perspective approach in south eastern Zimbabwe.

\begin{tabular}{|c|c|c|}
\hline Responses & Number $(n)$ & $\%$ \\
\hline \multicolumn{3}{|l|}{ Positive } \\
\hline Women gather forest products and have unique ecological knowledge that can assist in species conservation. & 3 & 60 \\
\hline Representation of rural women in the governance of natural resources should be increased & 5 & 100 \\
\hline Few women in CAMPFIRE leadership are the most trusted on financial management & 4 & 80 \\
\hline \multicolumn{3}{|l|}{ Negative } \\
\hline $\begin{array}{l}\text { Some customs limit women from participating in CAMPFIRE programs and/or prohibit them from } \\
\text { owning and controlling land and related natural resource assets }\end{array}$ & 4 & 80 \\
\hline The existing CAMPFIRE constitutions do not address gender participation in the CAMPFIRE programs & 3 & 60 \\
\hline
\end{tabular}


and from ministries to rural district councils of settlement.

Communities in the present study area were reported as having a poor record on gender equity and equality where men tend to dominate over women on control and decision making in society, and also men tend to be the sole think tank on livelihood matters [26] [27]. Attitudes such as, "women should-or should not-do this and that" or "men are supposed to do this_but not that", based on stereotypic views may prevent either women or men action regarding natural resource use, access, management or conservation [24].

To improve the role of women in natural resource management and conservation, there is need to better understand and target the reliance of women on natural resources capital, involve women more effectively in natural resource governance, and build the capacity of women in conservation science and its application since it has been noted that women are the main actors in natural resource utilisation [25] [28], despite being less actors in leadership for community based natural resource management.

Even when women attend meetings or events, they may not feel free to voice their opinions, or their opinions and needs may not be taken seriously [29] [30]. Community participation often favours local elites, usually men who directly conflict with and override poor women's access to natural resource products such as fuel wood and financial resources from safari hunting [31] [32] [33]. Despite attempts to mainstream gender at the national and international levels, few women participate. Although the international and national policies and agreements regulate the management and use of natural resources, most of these instruments do not highlight the potential gender-differentiated impacts of their provisions.

The Convention on Biological Diversity (CBD) and the Global Plans of Action recognize the key roles played by both women and men, especially in the developing world and the management and use of natural resources [34]. Unfamiliar with these policy instruments, extension workers, development agents, and people working on CBNRM will find it challenging to understand their impact and to implement the relevant provisions in their daily work [1] [2] [35]. The CBD advocates for fair and equitable sharing of genetic and natural resource benefits. It also establishes a connection between sustainable conservation and development and the rights of indigenous peoples and local communities [35]. However, despite the increased recognition of positive linkages between gender dynamics and household natural resource use, little progress has been shown in translating these into programmes which are pro-women centred CBNRM and conservation at the local level in developing countries, and Zimbabwe is no exception [7] [22] [35]. Rural women's vital contribution to the management of natural resources, and household food security remains misunderstood, ignored, or underestimated, yet women are important chain actors within the household food economy driven by natural resources harvested from the wilderness [35].

Women are not well represented in the governance of natural resources at lo- 
cal to global scales [15] [29] [36]. However, studies done in India and Nepal indicated that the inclusion of women in CBNRM resulted in improvements in natural forest community and its biodiversity [29] [37]. The involvement of women improved natural forest status because of enhanced forest ownership, guarding and rule compliance. Similarly, a study on the tropical wetland pan as a common water resource property reported high levels of collaboration, solidarity, and conflict resolution in natural resource management groups that involved women [15]. For instance, women in India formed the Chipko Movement when they recognized the negative link between deforestation and recurring floods and landslides [29]. Through lobbying and pressure group effect, they prevented tree felling and achieved a 10-year ban on logging in the affected area. In Kenya, the Green Belt Movement mobilized more than 80,000 women who planted more than 20 million trees [38]. Clearly, the representation of rural women in the governance of community natural resources need to be increased aimed at global natural resource conservation objectives.

Since one of the objectives of CAMPFIRE is to ensure improved livelihood and reduced societal inequality, incorporating women in CAMPFIRE leadership is ideal since they constitute the majority of the poor and socially disadvantaged population group in Zimbabwe [39]. CAMPFIRE programs around Gonarezhou National Park, south eastern Zimbabwe can expand pro-women livelihood activities such as fuel wood, the collection and sale of wild fruits [25] and mopane worms, and handicrafts. Gender insensitive CAMPFIRE programs may undermine ecologically sound and indigenous technical skills and knowledge on natural resource management which can be provided by women [40] [41]. There is a report that women in Zimbabwe have more in-depth indigenous technical skills and knowledge on tree species and their uses than men, which is partly a result of the women interacting with nature as they collect firewood, fodder, edible wild vegetables and fruit for their families [31]. The CBNRM institutions need to be inclusive. The study findings highlighted inadequate participation of the women and probably female youths in CAMPFIRE in south-eastern Zimbabwe. The emphasis has been to put on law enforcement, which favors males in the form of village scouts as natural resource overseers [1] [2]. Men dominate meetings and decision making over CAMPFIFRE in south-eastern Zimbabwe. Yet, it is the women who uses most of these natural resources such as game meat, wild vegetables and fish as relish, fuel wood as source of energy for cooking, and baskets woven from woodland products for carrying various household goods. A certain number of committee positions in CAMPFIRE need to be reserved for women.

\section{Conclusion}

The study aimed to understand the role women play in CBNRM in south-eastern Zimbabwe. Although the Zimbabwean Government included gender issues in CBNRM agenda, implementation efforts have been insufficient in other pro- 
grammes as highlighted by the present study. The study concluded that, despite all the benefits that a gender sensitive approach could bring to CBNRM; women still face major obstacles to participation and leadership of CAMPFIRE programs in southeast Zimbabwe. Women were not often elected by local people to lead CAMPFIRE programs and the existing CAMPFIRE constitutions do not address gender participation in the CAMPFIRE programs. Addressing the gender dimensions of CBNRM could help policymakers formulate more effective interventions for natural resource conservation and sustainable use (Patel, 1998). Thus, we recommended the following: Promote gender mainstreaming in the policies and operations of natural resource management institutions and ensure that women's and men's concerns and experiences are fully integrated. Promote the recognition of gender-differentiated roles, skills and practices in the conservation and sustainable use of natural resources, keeping in mind that these roles vary from place to place and change over time.

\section{Acknowledgements}

We thank the village leadership for permission to conduct this research, Chiredzi Rural District Council, and the CAMPFIRE committees in communities adjacent to Gonarezhou National Park.

\section{Conflicts of Interest}

The authors declare no conflicts of interest regarding the publication of this paper.

\section{References}

[1] Mashapa, C. (2018) Human Livelihoods and Sustainable Conservation: Herbivory and Anthropogenic Impacts on Woody Vegetation and Ecosystem Goods in Save Valley, Southeastern Lowveld of Zimbabwe. Ph.D. Thesis, Chinhoyi University of Technology, Chinhoyi.

[2] Mashapa, C., Gandiwa, E. and Muboko, N. (2019) Socio-Economic and Ecological Outcomes of Woodland Management in Mutema-Musikavanhu Communal Areas in Save Valley, Southeastern Lowveld of Zimbabwe. Journal of Animal and Plant Sciences, 29, 1075-1087.

[3] German, L.A., Colfer, C.J.P., Barrow, E., Küchli, C., Blaser, J. and Wardojo, W. (2010) Forest Governance and Decentralization in Africa: Linking Local, Regional and Global Dialogues. In: Governing Africa's Forests in a Globalized World, The Earthscan Forest Library, New York, 1-28. https://doi.org/10.4324/9781849774512

[4] Gandiwa, E., Zisadza-Gandiwa, P., Mashapa, C., Libombo, E. and Muboko, N. (2014) An Assessment of Local People Participation in Natural Resources Conservation in Southern Zimbabwe. Journal of Environmental Research and Management, 5, 42-46.

[5] Devkota, R.R. (2010) Interests and Power as Drivers of Community Forestry: A Case Study of Nepal. University of Göttingen, Göttingen. https://doi.org/10.17875/gup2010-281

[6] Mashapa, C., Mhuriro-Mashapa, P., Zisadza-Gandiwa, P. and Gandiwa, E. (2013) 
Adoption of Agro-Ecology Practices in Semi-Arid Environment of Chimanimani District, Eastern Zimbabwe. Journal of Sustainable Development in Africa, 15, 1-19.

[7] Mashapa, C., Gandiwa, E., Mhuriro-Mashapa, P. and Zisadza-Gandiwa, P. (2014) Increasing Demand on Natural Forest Products in Urban and Peri-Urban Areas of Mutare, Eastern Zimbabwe: Implications for Sustainable Natural Resources Management. Nature and Faune, 28, 42-48.

[8] Gandiwa, E., Zisadza-Gandiwa, P., Muboko, N., Libombo, E., Mashapa, C. and Gwazani, R. (2014) Local Peoples' Knowledge and Perceptions of Wildlife Conservation in Southeastern Zimbabwe. Journal of Environmental Protection, 5, 474-485. https://doi.org/10.4236/jep.2014.56050

[9] Murphree, M.W. (2009) The Strategic Pillars of Communal Natural Resource Management: Benefit, Empowerment and Conservation. Biodiversity and Conservation, 18, 2551-2562. https://doi.org/10.1007/s10531-009-9644-0

[10] Gandiwa, E., Heitkönig, I.M.A., Lokhorst, A.M., Prins, H.H.T. and Leeuwis, C. (2013) CAMPFIRE and Human-Wildlife Conflicts in Local Communities Bordering Northern Gonarezhou National Park, Zimbabwe. Ecological Society, 18, 7. https://doi.org/10.5751/ES-05817-180407

[11] Child, B. (2000) Making Wildlife Pay: Converting Wildlife's Comparative Advantage into Real Incentives for Having Wildlife in African Savannas, Case Studies from Zimbabwe and Zambia. In: Prins, H.T., et al., Eds., Wildlife Conservation by Sustainable Use, Volume 18, Springer, New York, 335-387. https://doi.org/10.1007/978-94-011-4012-6_17

[12] Logan, B.I. and Moseley, W.G. (2002) The Political Ecology of Poverty Alleviation in Zimbabwe's Communal Areas Management Programme for Indigenous Resources (CAMPFIRE). Geoforum, 33, 1-14. https://doi.org/10.1016/S0016-7185(01)00027-6

[13] Murphree, M.W. (2001) Community, Council and Client: A Case Study in Ecotourism Development from Mahenye, Zimbabwe. In: Hume, D. and Murphree, M.W., Eds., African Wildlife and Livelihoods. The Promise and Performance of Community Conservation, James Currey, Suffolk, 177-194.

[14] Muboko, N. and Murindagomo, F. (2014) Wildlife Control, Access and Utilisation: Lessons from Legislation, Policy Evolution and Implementation in Zimbabwe. Journal of Nature and Conservation, 22, 206-211. https://doi.org/10.1016/j.jnc.2013.12.002

[15] Westermann, O., Ashby, J. and Pretty, J. (2005) Gender and Social Capital: The Importance of Gender Differences for the Maturity and Effectiveness of Natural Resource Management Groups. World Development, 33, 1783-1799. https://doi.org/10.1016/j.worlddev.2005.04.018

[16] Moswete, N.N., Thapa, B. and Child, B. (2012) Attitudes and Opinions of Local and National Public Sector Stakeholders towards Kgalagadi Transfrontier Park, Botswana. International Journal of Sustainable Development and World Ecology, 19, 67-80. https://doi.org/10.1080/13504509.2011.592551

[17] Mutandwa, E. and Gadzirayi, C.T. (2007) Impact of Community-Based Approaches to Wildlife Management: Case Study of the CAMPFIRE Programme in Zimbabwe. International Journal of Sustainable Development and World Ecology, 14, 336-344. https://doi.org/10.1080/13504500709469734

[18] Gaidzanwa, R. (1994) Women's Land Rights in Zimbabwe. Issue, 22, 12-16. https://doi.org/10.2307/1166726

[19] Martino, D. (2008) Gender and Urban Perceptions of Nature and Protected Areas 
in Beñados del Este Biosphere Reserve. Environmental Management, 41, 654-662. https://doi.org/10.1007/s00267-008-9069-7

[20] Zimbabwe Parks and Wildlife Management Authority (ZPWMA) (2011) Gonarezhou National Park General Management Plan 2011-2021. Zimbabwe Parks and Wildlife Management Authority, Harare.

[21] Gandiwa, E. (2012) Local Knowledge and Perceptions of Animal Population Abundances by Communities Adjacent to the Northern Gonarezhou National Park, Zimbabwe. Tropical Conservation Science, 5, 255-269. https://doi.org/10.1177/194008291200500303

[22] CAMPFIRE Association (n.d.) What We Do. http://campfirezimbabwe.org/index.php/about-th/1-principles

[23] White, P.C.L., Jennings, N.V., Renwick, A.R. and Barker, N.H.L. (2001) Questionnaires in Ecology: A Review of Past Use and Recommendations for Best Practice. Journal of Applied Ecology, 42, 421-430. https://doi.org/10.1111/j.1365-2664.2005.01032.x

[24] Meekers, D. (1993) The Noble Custom of Roora: The Marriage Practices of the Shona of Zimbabwe. Ethnology, 32, 35-54. https://doi.org/10.2307/3773544

[25] Agarwal, B. (2003) Gender and Land Rights Revisited: Exploring New Prospects via the State, Family, and Market. Journal of Agrarian Change, 3, 184-224. https://doi.org/10.1111/1471-0366.00054

[26] Moyana, H.V. (1984) The Political Economy of Land in Zimbabwe. Mambo Press, Harare.

[27] Schmidt, E. (1992) Peasants, Traders and Wives: Shona Women in the History of Zimbabwe 1870-1939. In: Social History of Africa, Volume 13, Wiley, New York, $289 \mathrm{p}$.

[28] Kristof, N.D. and WuDunn, S. (2009) Saving the World's Women. The New York Times, 28.

[29] Agarwal, B. (2009) Gender and Forest Conservation: The Impact of Women's Participation in Community Forest Governance. Ecological Economics, 68, 2785-2799. https://doi.org/10.1016/j.ecolecon.2009.04.025

[30] Prokopy, L.S. (2004) Women's Participation in Rural Water Supply Projects in India: Is It Moving beyond Tokenism and Does It Matter? Water Policy, 6, 103-116. https://doi.org/10.2166/wp.2004.0007

[31] Fortmann, L. (1992) The Use of Indigenous Trees in Mhondoro District. Harare: Centre for Applied Social Science. University of Zimbabwe, Zimbabwe.

[32] Singh, N. (2006) Women's Participation in Local Water Governance: Understanding Institutional Contradictions. Gender, Technology and Development, 10, 61-76. https://doi.org/10.1177/097185240501000104

[33] Sultana, F. (2006) Gendered Waters, Poisoned Wells: Political Ecology of the Arsenic Crisis in Bangladesh. In: Lahiri-Dutt, K., Ed., Fluid Bonds: Views on Gender and Water, STREE, Kolkata, 362-387.

[34] Lambrou, Y and Laub, R. (2004) Gender Perspectives on the Conventions on Biodiversity, Climate Change and Desertification. Food and Agriculture Organization, Rome.

[35] Food and Agriculture Organization (FAO) (2005) Bioenergy-Committee on Agriculture. 19th Session, Rome, April 2005.

[36] Belsky, J.M. (2003) Unmasking the "Local": Gender, Community, and the Politics of Community-Based Rural Ecotourism in Belize. In: Brechin, S.R., Wilshusen, P.R., 
Fortwangler, C.L. and West, P.C., Eds., Contested Nature. Promoting International Biodiversity Conservation with Social Justice in the Twenty-First Century, State University of New York Press, Albany, NY, 89-101

[37] Shrestha, K.K. (2005) Collective Action and Equity in Nepalese Community Forestry. The University of Sydney, Sydney.

[38] Wangari Maathai Foundation (2015) Green Belt Movement. National Council of Women of Kenya University of Nairobi, Kenya.

[39] ZimVac (2015) Zimbabwe Vulnerability Assessment Committee, Zimbabwe Rural Livelihoods Assessment May 2015 Report. Food and Nutrition Council. SIRDIC, Harare.

[40] Nyoni, S. (1985) Africa's Food Crisis: Price of Ignoring Village Women? In: Women and the Environment Crisis, Environment Liaison Centre, Nairobi.

[41] Dankelman, I. and Davidson, J. (1988) Women and Environment in the Third World. Earthscan Publications, Ltd., London. 